\title{
OXIDIZABLE FRACTION OF ORGANIC CARBON IN AN ARGISOL UNDER DIFFERENT LAND USE SYSTEMS
}

\author{
Caio Batista Müller ${ }^{1}$, Oscarlina Lúcia dos Santos Weber², José Fernando Scaramuzza³
}

(received: August 16, 2010; accepted: December 22, 2011)

\begin{abstract}
The objective of this study was to evaluate carbon input in labile and stable fractions in an ARGISOL of northwestern Brazil under different land use systems. Use systems being evaluated include: forest - MA (reference), agrosilvopasture - TCP (teak, cocoa and pasture); agroforest - TC (teak and cocoa); teak forest at 8 and 5 years - T8 and T5, and pasture - PA. In each system three furrows were made at depths of $0-5 \mathrm{~cm}, 5-10 \mathrm{~cm}$ and $10-20 \mathrm{~cm}$. An area consisting of native vegetation (forest) adjacent to the experiment was sampled and used as control treatment. The use systems MA, T8 and T5 had higher levels of total organic carbon (COT) and the MA system had higher levels of labile carbon (CL) than the other systems, with the exception of TC at a depth of 10-20 cm. In the MA system, COT levels were higher in comparison to use systems TCP, TC and PA while CL levels were higher than the levels observed in use systems TCP and TC. In most cases being analyzed, CL levels were lower than COT levels, therefore this trait can be used as an indicator to assess anthropogenic changes relating to the maintenance or condition of soil organic matter.
\end{abstract}

Key words: Soil compartments, Amazonia, lability.

\section{FRAÇÃO OXIDÁVEL DO CARBONO ORGÂNICO DE UM ARGISSOLO SOB DIFERENTES SISTEMAS DE USO}

\begin{abstract}
RESUMO: Neste estudo, objetivou-se avaliar o aporte de carbono nas frações lábil e não lábil em um ARGISSOLO do noroeste brasileiro, em diferentes sistemas de uso do solo. Os sistemas de uso avaliados foram: mata-MA (referência), agrossilvopastoril-TCP (teca, cacau e pasto); agroflorestal - TC (teca e cacau); florestal teca com 8 e 5 anos - T8 e T5 e pastagem-PA. Em cada sistema foram abertas três trincheiras nas profundidades de 0 a 5; 5 a 10 e 10 a $20 \mathrm{~cm}$. Uma área sob vegetação nativa (mata) adjacente ao experimento foi amostrada e usada como referência. Os sistemas de uso MA, T8 e T5 tiveram maiores teores de carbono orgânico total (COT) e o sistema MA de carbono lábil (CL) do que os demais sistemas, com exceção do TC na profundidade de 10 a $20 \mathrm{~cm}$. No sistema MA, os teores de COT foram maiores em relação ao sistema de uso TCP, TC e PA e os teores de CL foram maiores do que os observados nos sistemas de uso TCP e TC. Os teores do CL, na maioria dos casos analisados, foram menores que os de COT e, por essa razão, esse atributo pode ser usado como indicador para avaliar as mudanças antropogênicas na manutenção ou no estado da matéria orgânica do solo.
\end{abstract}

Palavras-chave: Compartimentos do solo, Amazônia, labilidade.

\section{INTRODUCTION}

Oxidizable or labile fraction is intended to describe the biologically active components of soil organic matter (MOS), being a constituent part of organic compounds more rapidly mineralizable in reactions catalyzed by microbial enzymes present in the soil, and thus directly associated with $\mathrm{CO}_{2}$ release into the atmosphere (TAVARES, 2010). According to Powlson et al. (1987), labile carbon is susceptible to alterations brought about by changes in the environment. More prone to variations than total soil organic carbon, it enables greater applicability for detection of impacts brought about by different land use systems, in connection with soil and air quality.
Every organic fraction present in the soil in the form of residue is MOS and may include fresh and partially decomposed matter, humus composts and charred material, whether associated or not with the mineral fraction, and another part constituted by the living biomass of organisms (ROSCOE; MACHADO, 2002).

MOS levels are very susceptible to forest management practices, particularly in regions of tropical and subtropical climate, in which the exposed organic matter is decomposed by bioactive organisms (AGUIAR et al., 2009). Likewise, when MOS is protected in the interior of smaller soil aggregates or by strong bonding to the mineral fraction, its levels may remain close to original levels for several crop years (CONTE et al., 2011).

\footnotetext{
${ }^{1}$ Agronomist, Professor M.Sc. in Tropical Agriculture - Faculdade Integrada de Sorriso - Av. Noeme Tonello Dalmolin, 2499, Bairro Universitário Cx. P. 475 - 78980-000 - Sorriso, MT, Brasil - caiomuller@hotmail.com

${ }^{2}$ Agronomist, Professor Ph.D. in Soils and Plant Nutrition - Departamento de Solos e Engenharia Rural - Faculdade de Agronomia, Medicina Veterinária e Zootecnia - Universidade Federal de Mato Grosso/UFMT - 78060-900 - Cuiabá, MT, Brasil - oscsanwb@ufmt.br

${ }^{3}$ Agronomist, Professor Ph.D. in Plant Science/Plant Production - Departamento de Solos e Engenharia Rural - Faculdade de Agronomia, Medicina Veterinária e Zootecnia - Universidade Federal de Mato Grosso/UFMT - 78060-900 - Cuiabá, MT, Brasil - jscaramuzza@uol.com.br
}

Cerne, Lavras, v. 18, n. 2, p. 215-222, abr./jun. 2012 
Roscoe and Buurmam (2003) found MOS levels close to original vegetation levels after 30 crop years in Red Latosols cultivated by using both no-till and conventional tillage systems.

In order to determine whether and in which compartments $\mathrm{C}$ is being accumulated, methods have been used of physical fractionation of MOS that include granulometric techniques (MARTINS et al., 2009), densimetric techniques or a mixture of both (CONCEIÇÃO et al., 2008).

The organic fraction of soil composed of soil carbon plays a key role in the sustainability of that soil and in the sustainability of production systems (BODDEY et al., 2010).

Carbon (C) may accumulate in labile or stable fractions of MOS, which may affect the durability of its effect regarding retention time in the atmosphere, causing changes to the physical, chemical and biological properties of soils (FELLER; BEAR, 1997).

The residence time of every labile fraction protected inside soil aggregates is greater than the free fraction, it being better protected in microaggregates than in macroaggregates (SIX et al., 2006). This justifies the accumulation of $\mathrm{C}$ in labile fractions of MOS, as a result of difficult organism accessibility (BAYER et al., 2004).

Looking to obtain indices to assess the effectiveness of different land use systems and different types of management and thus promote soil quality and agroecosystem sustainability, Blair et al. (1995) proposed a Carbon Management Index (IMC) which takes into consideration aspects of MOS lability. It is calculated by computing the Carbon Pool Index (ICC) and the Lability Index (IL).

ICC is the ratio of total organic carbon of the sampled system to organic carbon of the reference system $(\mathrm{ICC}=\mathrm{COT}$ of used system /COT of reference system), and IL is obtained by computing the ratio of carbon lability of the sampled system to carbon lability of the reference system ( $\mathrm{IL}=\mathrm{L}$ of used system $/ \mathrm{L}$ of reference system).

With the above in mind, the objective of this work was to evaluate $\mathrm{C}$ levels in the labile and stable fractions of MOS, in a region of northwestern Brazil subjected to different land use systems.

\section{MATERIAL AND METHODS}

\subsection{Characteristics of the study site}

The project was carried out in a private property located $13.5 \mathrm{~km}$ away from Colorado do Oeste, southern
Rondônia state, between geographical coordinates $13^{\circ} 09^{\prime} 29.4^{\prime \prime}$ south latitude and $60^{\circ} 37^{\prime} 50.6^{\prime \prime}$ west longitude, at an altitude of 330-417 meters, with an average maximum temperature of $35^{\circ} \mathrm{C}$ and an average minimum temperature of $19^{\circ} \mathrm{C}$, and average annual precipitation exceeding $2.000 \mathrm{~mm}$ (RONDÔNIA, 2002).

For this study, six areas in close proximity to each other were selected (Figure 1), including: (i) primary forest vegetation/native forest (MA), (ii) agrosilvopasture consisting of teak, cocoa and pastureland (TCP), (iii) agroforest consisting of teak and cocoa (TC), (iv and v) forest consisting of teak at 8 years and teak at 5 years (T8 and T5) and (vi) pastureland cultivated with Brachiaria brizantha (PA). Soil was sampled in three furrows of $40 \times 60 \times 20 \mathrm{~cm}$ at depths of $0-5 \mathrm{~cm}, 5-10 \mathrm{~cm}$ and $10-20 \mathrm{~cm}$, for each land use system. The land use history of each of these areas is summarized in Table 1.

According to Köppen classification, the local climate is Aw type, hot and humid with tropical rains, having two well defined seasons: summer from May to September which is when lower rates of rainfall are observed, around $750-810 \mathrm{~mm}$, that is, $30 \%$ to $40 \%$ of the total, and winter from October to April, which is when higher rates of rainfall occur, around 1,470-1,500 mm or $60 \%$ of the total, with daily rain over a period of 100 days (RONDÔNIA, 2002).

The relief in the experimental area is mountainous, with most of the town of Colorado do Oeste (RO) sitting in the southwestern slope of the Parecis plateau at altitudes $400 \mathrm{~m}$ above sea level. The predominating soil types in areas of smoothly rugged terrain are eutrophic Red-Yellow Argisols, eutrophic Red Argisols, eutrophic Cambisols, while in smoother terrain the predominating soils are dystrophic Yellow Latosols and Quartzarenic Neosols (RONDÔNIA, 2002).

\subsection{Determination of total organic carbon and labile carbon}

The total soil organic carbon (COT) was quantified via wet oxidation of the organic matter, using a potassium dichromate solution in acidic medium, with an external heat source (YEOMANS; BREMNER, 1988). The labile carbon was quantified via oxidation with $\mathrm{KMnO}_{4}\left(333 \mathrm{mmol} . \mathrm{L}^{-1}\right)$, as proposed by Blair et al. (1995) and modified by Shang and Tiessen (1997), while the stable carbon (CNL), which is the $\mathrm{C}$ not oxidized by $\mathrm{KMnO}_{4}$, was given as the difference $(\mathrm{CNL}=\mathrm{COT}-\mathrm{CL})$.

Cerne, Lavras, v. 18, n. 2, p. 215-222, abr./jun. 2012 


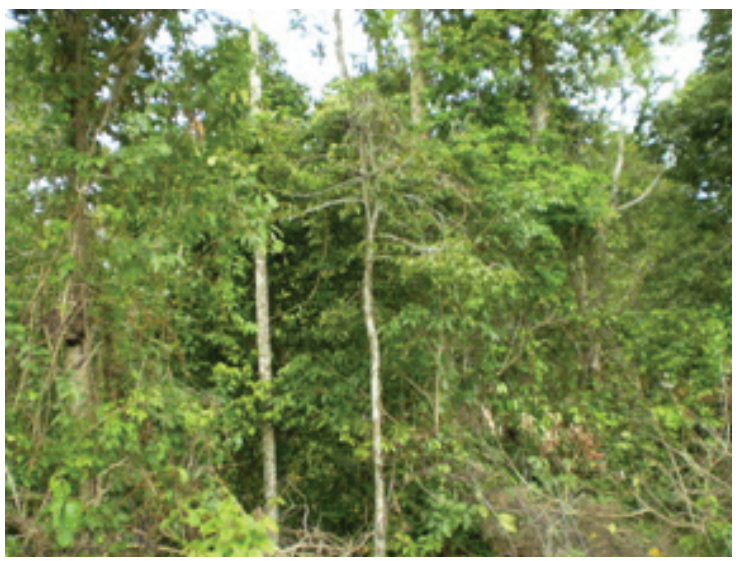

Forest

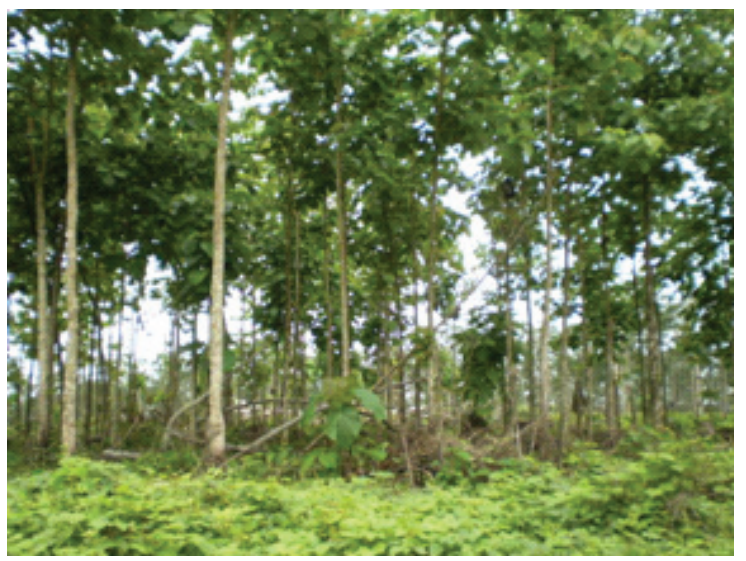

Teak 5 years

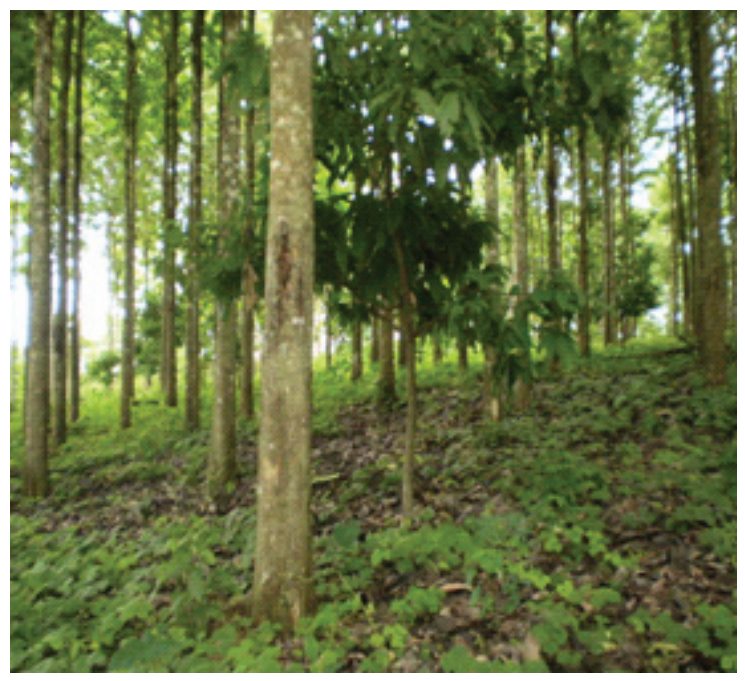

Teak and cocoa

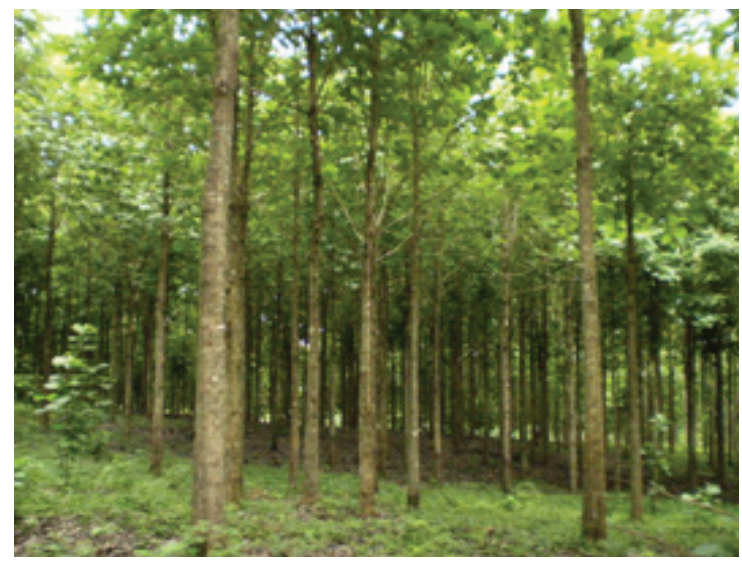

Teak 8 years

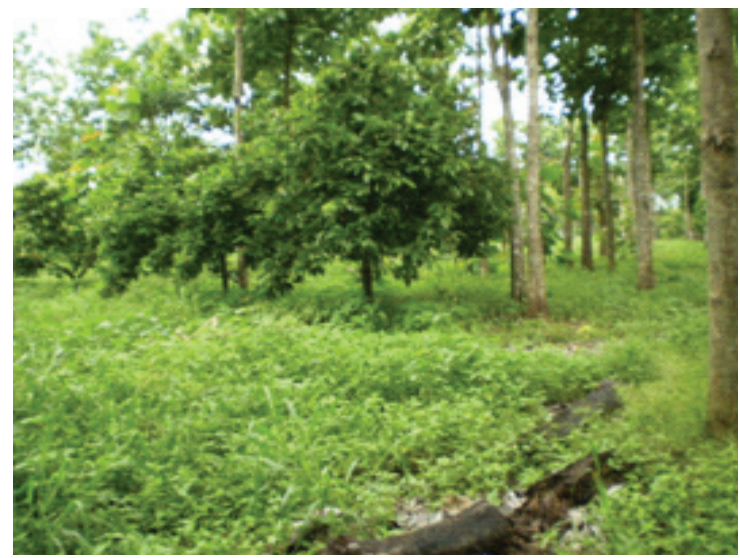

Teak, cocoa and pasture

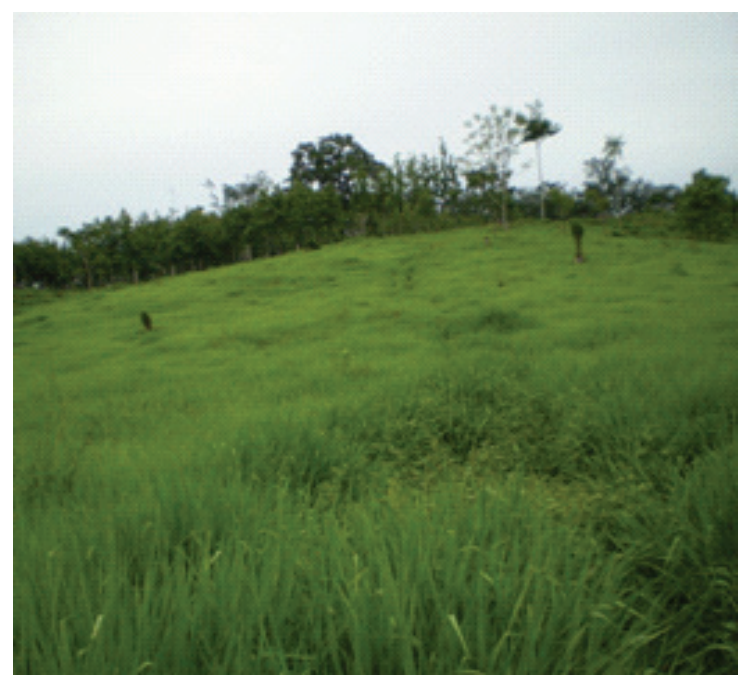

Pasture

Figure 1 - General view of locations where soil was sampled.

Figura 1 -Vista geral dos locais onde foram retiradas as amostras de solo. 
Table 1 - Characteristics of the land use systems in each selected area.

Tabela 1 - Características dos sistemas de uso das áreas escolhidas.

\begin{tabular}{|c|c|c|}
\hline Use system & Symbol & History \\
\hline Native Forest & MA & $\begin{array}{l}\text { Area of open semideciduous submontane tropical forest, emergent canopy having } \\
\text { about } 20 \% \text { to } 50 \% \text { of deciduous trees in drought periods. }\end{array}$ \\
\hline $\begin{array}{l}\text { Agroforest system with } \\
\text { teak at five years }\end{array}$ & $\mathrm{T} 5$ & $\begin{array}{l}\text { Teak introduced in December } 2001 \text { in } 7.0 \text { ha, with spacing of } 3 \times 2 \mathrm{~m} \text {, where the } \\
\text { primary forest had been manually felled, followed by burning. In the first two years } \\
\text { rice, corn and beans were intercropped in between rows, followed by soil coverage } \\
\text { with kudzu (Pueraria montana) }\end{array}$ \\
\hline $\begin{array}{l}\text { Agroforest system with } \\
\text { teak at eight years }\end{array}$ & $\mathrm{T} 8$ & $\begin{array}{l}\text { Teak introduced in 1998, where the primary forest had been manually felled in June } \\
\text { 1975, followed by burning, and then coffee planting (Coffea canephora). In between } \\
\text { rows, it was intercropped with rice, corn and beans for } 4 \text { years, with no fertilization. } \\
\text { In year five, a grass pasture was introduced (Brachiaria brizantha). Nine years later, } \\
\text { in 1984, pine (Schizolobium amazonicum) was planted in } 10 \text { ha with spacing of } 3 \times 5 \\
\text { m between plants. As some seedlings died, teak was planted to replace them. In } \\
\text { December 2000, the soil was covered with Kudzu (Pueraria montana). }\end{array}$ \\
\hline $\begin{array}{l}\text { Agroforest system with } \\
\text { teak, cocoa and pasture }\end{array}$ & TCP & $\begin{array}{l}\text { Teak introduced in 1998, the history of the area being the same as for T8, yet in } \\
\text { December } 2000 \text { a portion of this area in between trees in the rows was intercropped } \\
\text { with cocoa, with only teak and pasture remaining in the area. }\end{array}$ \\
\hline $\begin{array}{l}\text { Agroforest system with } \\
\text { teak and cocoa }\end{array}$ & $\mathrm{TC}$ & $\begin{array}{l}\text { Teak introduced in 1998, the history of the area being the same as for } \mathrm{T} 8 \text {, yet in } \\
\text { December } 2000 \text { a portion of this area in between trees in the rows was intercropped } \\
\text { with cocoa, with only teak remaining in the area }\end{array}$ \\
\hline Extensive pasture & $\mathrm{PA}$ & $\begin{array}{l}\text { Area opened in 2001, with manual tree felling, followed by burning and planting of } \\
\text { grass (Brachiaria brizantha), which was extensively yet unevenly grazed by cattle, } \\
\text { with some areas being underused and other areas, overused. }\end{array}$ \\
\hline
\end{tabular}

$1 \mathrm{~g}$ of the soil sample was passed through a $0.5 \mathrm{~mm}$ sieve, containing around $25 \mathrm{mg}$ of organic $\mathrm{C}$, with samples being placed in $50 \mathrm{~mL}$ centrifuge tubes and adding $25 \mathrm{~mL}$ of the $\mathrm{KMnO}_{4} 333 \mathrm{mmol} . \mathrm{L}^{-1}$ solution. The tubes were then capped and shaken for one hour at $60 \mathrm{rpm}$ in a horizontal shaker, followed by centrifugation at $2,000 \mathrm{rpm}$ for five minutes. $1.0 \mathrm{~mL}$ of the supernatant was pipetted into a $250 \mathrm{~mL}$ volumetric flask, completing the volume with deionized water. To construct the standard curve $1.0 \mathrm{~mL}$ was pipetted from six standard solutions of $\mathrm{KMnO}_{4}$ with concentrations ranging from 280 to $333 \mathrm{mmolL}^{-1}$, using the same dilution ratio.

The absorbance of the solutions was determined using a spectrophotometer with a selected wavelength of $565 \mathrm{~nm}$. The variation in $\mathrm{KMnO}_{4}$ concentration, as read from the standard curve, was used for estimating the amount of oxidized $\mathrm{C}$ (labile $\mathrm{C}$ ) considering that 1.0 mol of $\mathrm{KMnO}_{4}$ was consumed in the oxidation of 0.75 mol $(9 \mathrm{~g})$ of carbon. Based on the changes in COT from a reference system to a sampled system, a Carbon Pool Index (ICC) was calculated as follows: ICC = cultivated COT/ reference COT. Based on the changes in the proportion of $\mathrm{CL}$ (i.e. $\mathrm{L}=\mathrm{CL} / \mathrm{CNL}$ ) in the soil, a Lability Index (IL) was determined as follows: $\mathrm{IL}=$ cultivated $\mathrm{L} /$ reference $\mathrm{L}$. These two indices were used for calculating the Carbon Management Index (IMC), given as follows: IMC = ICC x IL x 100 (BLAIR et al., 1995).

This experiment used a completely randomized design with three replicates for each land use system. Treatments consisted of one reference sample (native vegetation/forest) and five different land use systems.

Data were subjected to analysis of variance and the means test (Scott-Knott at the 5\% probability level), according to Banzatto and Kronka (1992), using SAEG software (RIBEIRO JÚNIOR, 2001).

\section{RESULTS AND DISCUSSION}

CL levels were higher $(\mathrm{p}<0.05)$ respectively in the MA, T5, T8 systems, followed by the PA system (Table 2), in the $0-5 \mathrm{~cm}$ and $5-10 \mathrm{~cm}$ layers. For all systems, higher values were observed within a single system at the depth of $10-20 \mathrm{~cm}$ due to the protection of soil aggregates at greater depths. The greatest difference in CL level relative to the MA system was found for the TC system.

Cerne, Lavras, v. 18, n. 2, p. 215-222, abr./jun. 2012 
Table 2 - Labile and stable organic carbon in different land use systems.

Tabela 2 - Carbono orgânico lábil e não lábil em diferentes sistemas de uso.

\begin{tabular}{|c|c|c|c|c|c|c|c|c|}
\hline \multirow[t]{3}{*}{ Treat } & Depth & $\mathrm{CL}$ & $\mathrm{CNL}$ & COT & ICC & IL & IMC & $\mathrm{L}$ \\
\hline & & \multicolumn{7}{|c|}{ 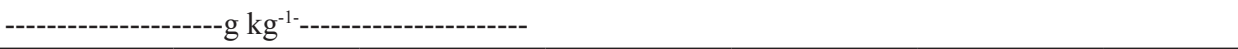 } \\
\hline & $0-5$ & $4.85 \mathrm{Ba}$ & $15.02 \mathrm{Aa}$ & $19.87 \mathrm{Aa}$ & 1.00 & 1.00 & $100 \mathrm{Aa}$ & 0.3229 \\
\hline \multirow[t]{3}{*}{ MA } & $5-10$ & $5.26 \mathrm{Ba}$ & $10.50 \mathrm{Aa}$ & $15.76 \mathrm{Aa}$ & 1.00 & 1.00 & $100 \mathrm{Aa}$ & 0.5010 \\
\hline & $10-20$ & $5.41 \mathrm{Aa}$ & $3.38 \mathrm{Ba}$ & $8.79 \mathrm{Ba}$ & 1.00 & 1.00 & $100 \mathrm{Aa}$ & 2.6933 \\
\hline & $0-5$ & $3.87 \mathrm{Bb}$ & $14.70 \mathrm{Aa}$ & $18.57 \mathrm{Aa}$ & 0.93 & 0.82 & $76.20 \mathrm{Ab}$ & 0.2633 \\
\hline \multirow[t]{3}{*}{$\mathrm{T} 8$} & $5-10$ & $4.25 \mathrm{Bb}$ & $11.49 \mathrm{Aa}$ & $15.74 \mathrm{Aa}$ & 1.00 & 0.74 & $73.74 \mathrm{Aa}$ & 0.3699 \\
\hline & $10-20$ & $5.32 \mathrm{Aa}$ & $2.56 \mathrm{Ba}$ & $7.88 \mathrm{Ba}$ & 0.90 & 0.77 & $69.17 \mathrm{Bb}$ & 2.0781 \\
\hline & $0-5$ & $3.74 \mathrm{Bb}$ & $13.91 \mathrm{Aa}$ & $17.65 \mathrm{Aa}$ & 0.89 & 0.83 & $73.96 \mathrm{Ab}$ & 0.2689 \\
\hline \multirow[t]{3}{*}{ T5 } & $5-10$ & $4.66 \mathrm{Ab}$ & $9.96 \mathrm{Aa}$ & $14.62 \mathrm{Aa}$ & 0.93 & 0.93 & $86.64 \mathrm{Aa}$ & 0.4679 \\
\hline & $10-20$ & $5.31 \mathrm{Aa}$ & $2.54 \mathrm{Ba}$ & $7.85 \mathrm{Ba}$ & 0.89 & 0.78 & 69.32 Ac & 2.0906 \\
\hline & $0-5$ & $3.45 \mathrm{Bb}$ & $10.87 \mathrm{Ab}$ & $14.32 \mathrm{Ab}$ & 0.72 & 0.98 & $70.84 \mathrm{Ab}$ & 0.3174 \\
\hline \multirow[t]{3}{*}{ TCP } & $5-10$ & $4.20 \mathrm{Ab}$ & $6.45 \mathrm{Bb}$ & $10.65 \mathrm{Ab}$ & 0.68 & 1.30 & $87.84 \mathrm{Aa}$ & 0.6512 \\
\hline & $10-20$ & $4.80 \mathrm{Ab}$ & $3.11 \mathrm{Ca}$ & $7.91 \mathrm{Ba}$ & 0.90 & 0.57 & $51.57 \mathrm{Bd}$ & 1.5434 \\
\hline & $0-5$ & $3.25 \mathrm{Bb}$ & $12.6 \mathrm{Ab}$ & $15.85 \mathrm{Ab}$ & 0.80 & 0.80 & $63.72 \mathrm{Bc}$ & 0.2579 \\
\hline \multirow[t]{3}{*}{$\mathrm{TC}$} & $5-10$ & $4.12 \mathrm{Bb}$ & $5.55 \mathrm{Bc}$ & $9.67 \mathrm{Bb}$ & 0.61 & 1.48 & $90.92 \mathrm{Aa}$ & 0.7423 \\
\hline & $10-20$ & $4.70 \mathrm{Ab}$ & $2.45 \mathrm{Ca}$ & $7.15 \mathrm{Ba}$ & 0.81 & 0.71 & $57.94 \mathrm{Bc}$ & 1.9184 \\
\hline & $0-5$ & $3.87 \mathrm{Bb}$ & $9.98 \mathrm{Ab}$ & $13.85 \mathrm{Ab}$ & 0.70 & 1.20 & $83.71 \mathrm{Aa}$ & 0.3878 \\
\hline \multirow[t]{2}{*}{$\mathrm{PA}$} & $5-10$ & $4.25 \mathrm{Ab}$ & $4.96 \mathrm{Bc}$ & $9.21 \mathrm{Ab}$ & 0.58 & 1.71 & $99.96 \mathrm{Aa}$ & 0.8569 \\
\hline & $10-20$ & $5.24 \mathrm{Aa}$ & $1.75 \mathrm{Cb}$ & $6.99 \mathrm{Ba}$ & 0.80 & 1.11 & $88.41 \mathrm{Aa}$ & 2.9943 \\
\hline
\end{tabular}

$\mathrm{MA}^{1}=$ forest, $\mathrm{T}^{2}$ teak 8 years, $\mathrm{T}^{3}=$ teak 5 years, $\mathrm{TCP}^{4}=$ teak, cocoa and pasture, $\mathrm{TC}^{5}=$ teak and cocoa, $\mathrm{PA}{ }^{6}=$ pasture. $\mathrm{CL}=$ labile carbon, $\mathrm{CNL}=$ stable carbon, $\mathrm{COT}=$ total organic carbon, $\mathrm{ICC}=$ carbon pool index, $\mathrm{IL}=$ lability index, $\mathrm{IMC}=$ carbon management index and L=lability. "Means followed by different letters, a capital letter within the same system and a small letter between different systems, differ from each other by the Scott-Knott test $(\mathrm{P}<0.05)$.

CL levels in the MA system at the depths of $0-5 \mathrm{~cm}$ and $5-10 \mathrm{~cm}$ were higher than in all systems being evaluated, similarly to results found by Zinn (2005).

All land use systems and all three layers being considered, it was found that CL levels increased with deeper depths due to greater protection of organic matter there.

The MA system had the highest level of the CL fraction $\left(4.85 \mathrm{~g} \mathrm{~kg}^{-1}\right)$ in the $0-5 \mathrm{~cm}$ layer, while the $\mathrm{TC}$ system had the lowest CL fraction $\left(3.25 \mathrm{~g} \mathrm{~kg}^{-1}\right)$, a result that demonstrates that in the uppermost layer there can be losses due to erosion, reduced microbial activity or other losses that include exposure to the sun. This fraction also decreased in the 5-10 $\mathrm{cm}$ layer $\left(1.14 \mathrm{~g} \mathrm{~kg}^{-1}\right)$ when comparing the MA system with the TC system, while in the $10-20 \mathrm{~cm}$ layer the amount of lost CL decreased, the greatest loss being $0.61 \mathrm{~g}$ $\mathrm{kg}^{-1}$ from the MA system to the TC system, possibly more favorable to microbial activity and less protection of the CL inside smaller aggregates, similarly to results found by Bavoso et al. (2010) and Ferreira et al. (2011).

A difference was found $(\mathrm{p}>0.05)$ in CL levels at the $0-5 \mathrm{~cm}$ and $5-10 \mathrm{~cm}$ depths between the MA system and the other systems (T5, T8, PA, TCP and TC). The difference found in the $10-20 \mathrm{~cm}$ layer between MA and TC regarding CL, according to Aguiar et al. (2009), was probably due to the lack of grass species to help structure the soil. Bavoso et al. (2010) concluded that different land use systems did to add significant values of MOS accumulation between the sampled systems, and results confirm and demonstrate that CL levels in the MOS are largely susceptible to the quality of soil management systems, enabling to check the short- and medium-term effect depending on the management being used (FABRIZZI et al., 2008, cited by CHAVEZ et al., 2009).

Cerne, Lavras, v. 18, n. 2, p. 215-222, abr./jun. 2012 
The higher CL values found in MOS of the MA system, in surface layers, are related to greater addition and decomposition of plant residues on the soil surface, reduced microbial activity due to dropping soil temperature and increasing aeration, there also being greater physical protection of the MOS inside soil aggregates (BALESDENT et al., 2000).

As regards stable carbon (CNL), a difference was found in the $0-5 \mathrm{~cm}$ layer between the MA system and the TCP and PA systems, a decrease of $27.6 \%$ being found for the TCP system, and $33.5 \%$ for the TC system. A difference was also found in the $5-10 \mathrm{~cm}$ layer between the MA and the TCP, TC and PA systems. In the 10-20 cm layer, a difference was observed for the MA and PA systems in relation to the other systems, probably due to less accumulation of pasture-originated material. Aggregation is associated to physical protection of labile fractions of MOS, reducing biodegradation (BALESDENT et al., 2000).

Unlike CL, CNL had higher values for the MA and for the T8 and T5 systems, at $0-5 \mathrm{~cm}$ and $5-10 \mathrm{~cm}$ depths. At the 10-20 cm depth, PA was the only system showing a difference, providing the lowest results, probably due to the greater quantity of grass species in this system, as observed by Kluthcouski et al. (2006).

As for the carbon management index (IMC), a statistical difference was found in the $0-5 \mathrm{~cm}$ layer for the MA and PA system in relation to the other systems, with similar results found by Fraga (2002), it also being noted that the greater the intensity of crop cultivation and soil exposure, the lower IMC values are. In the 5-10 cm layer, there was no difference between the other systems and the MA system. In the $10-20 \mathrm{~cm}$ layer, a difference was observed for the MA and PA system in relation to the other use systems, similarly to results found by Leite et al. (2003), who found IMC values above 100 in pasture systems.

The IMC value in the $5-10 \mathrm{~cm}$ layer did not differ between the systems. In the studied profile $(0-20 \mathrm{~cm})$, the IMC ranged from 51.57 (TCP 10-20 cm) to 99.96 (TC $5-10 \mathrm{~cm}$ ) within the use systems. As cited by Blair et al. (1995) and confirmed by several researchers, IMC values below 100 are typically found in studies where land use and management practices are degrading and indicative of a negative impact on the levels of organic matter, affecting soil quality as a result (COSTA et al., 2004), as was observed in all systems, with all layers having values below 100 . Therefore, the most negatively affecting system at the $0-5 \mathrm{~cm}$ layer was the TC system, followed by the T8 system at the $5-10 \mathrm{~cm}$ layer, and the TCP system at the 10-20 $\mathrm{cm}$ depth layer.

Cerne, Lavras, v. 18, n. 2, p. 215-222, abr./jun. 2012
All land use systems contributed to a reduction in the COT levels with increased depth, and at surface level the differences between systems were probably due to greater exposure of organic material to the effects of rain and sunlight in some systems (RIBEIRO et al., 2011). Therefore, the land use systems where organic matter was less exposed to degradation, including MA, T8 and T5, had better preserved COT levels. One possible reason for this is that the MA system having greater diversity of organic material, as reported by Faria et al. (2008) and Leite et al. (2003), there is continuous input and deposition of material on the soil surface. With the T5 and T8 systems, the deposited organic material is composed of leaves, branches and miscellaneous matter as was also reported by Almeida et al. (2010). Although the PA system did not contribute to COT at depth, the IMC and CL contributed in such way that even without organic input being deposited on its surface, this system explores the soil volume and preserves the aggregates, proving as efficient as the MA system in preserving CL levels, as was verified by Conte et al. (2011).

\section{CONCLUSION}

Manual felling of native vegetation, followed by burning and crop cultivation in the first two years, dramatically decreases soil carbon levels.

Different land use systems changed total organic carbon levels and oxidizable fractions. Labile carbon levels were reduced more intensely than total organic carbon levels, with the MA system having higher labile carbon levels.

Intercropped systems had higher IMC values in the surface layer $(0-5 \mathrm{~cm})$, while the PA system had a higher value for this index in the $5-10 \mathrm{~cm}$ layer.

\section{REFERENCES}

AGUIAR, N. de O.; CANELLAS, L. P.; DOBBSS, L. B.; ZANDONADI, D. B.; OLIVARES, F. L.; FAÇANHA, A. R. Distribuição de massa molecular de ácidos húmicos e promoção do crescimento radicular. Revista Brasileira de Ciência do Solo, Campinas, v. 33, n. 6, p. 1613-1623, 2009.

ALMEIDA, E. M.; CAMPELO JÚNIOR, J. H.; FINGER, Z. Determinação do estoque de carbono em teca (Tectona grandis L. F.) em diferentes idades. Ciência Florestal, Santa Maria, v. 20, n. 4, p. 559-568, 2010. 
BALESDENT, J.; CHENU, C.; BALABANE, M. Relationship of soil organic matter dynamics to physical protection and tillage. Soil and Tillage Research, Amsterdam, v. 53, p. 215-230, 2000.

BANZATTO, D. A.; KRONKA, S. N. Experimentação agrícola. Jaboticabal: FUNEP, 1992. 247 p.

BAVOSO, M. A.; GIAROLA, N. F. B.; FABIOLA, N.; TORMENA, C. A.; PAULETTI, V. Preparo do solo em áreas de produção de grãos, silagem e pastejo: efeito na resistência tênsil e friabilidade de agregados. Revista Brasileira de Ciência do Solo, Campinas, v. 34, p. 227-234, 2010.

BAYER, C.; MARTIN-NETO, L.; MIELNICZUK, J.; PAVINATO, A. Armazenamento de carbono em frações lábeis da matéria orgânica de um Latossolo Vermelho sob plantio direto. Pesquisa Agropecuária Brasileira, Brasília, v. 39, n. 7, p. 677-683, jul. 2004.

BLAIR, G. J.; LEFROY, R. D. B.; LISLE, L. Soil carbon fractions based on their degree of oxidation, and development of a carbon management index for agricultural systems. Australian Journal of Agriculture Research, Melbourne, v. 46, p. 1459-1466, 1995.

BODDEY, R. M.; JANTALIA, C. P.; CONCEICÃO, P. C.; ZANATTA, J. A.; BAYER, C.; MIELNICZUK, J.; DIECKOW, J.; SANTOS, H. P.; DENARDIN, J. E.; AITA, C.; GIACOMINI, S. J.; ALVES, B. J. R.; URQUIAGA, S. Carbon accumulation at depth in Ferralsols under zerotill subtropical agriculture. Global Change Biology, Oxford, v. 16, p. 784-795, 2010.

CHAVEZ, L. F.; AMADO, T. J. C.; BAYER, C.; LA SCALA, N. J.; ESCOBAR, L. F.; FIORIN, J. E.; CAMPOS, B.

H. C. de. Carbon dioxide efflux in a rhodic hapludox as affected by tillage systems in southern. Revista Brasileira de Ciência do Solo, Campinas, v. 33, n. 2, mar./abr. 2009. Disponível em: $<$ http://www.scielo.br/scielo.php?pid=S010006832009000200010\&script=sci_arttext $>$. Acesso em: 10 mar. 2010.

CONCEIÇÃO, P. C.; BOENI, M.; DIECKOW, J.; BAYER, C.; MIELNICZUK, J. Fracionamento densimétrico com politungstato de sódio no estudo da proteção física da matéria orgânica em solos. Revista Brasileira de Ciência do Solo, Campinas, v. 32, p. 541-549, 2008.

CONTE, O.; WESP, C. de L.; ANGHINONI, I.; CARVALHO, P. C. de F.; LEVIEN, R.; NABINGER, C. Densidade, agregação e frações de carbono de um argissolo sob pastagem natural submetida a níveis de ofertas de forragem por longo tempo. Revista Brasileira de Ciência do Solo, Campinas, v. 35, p. 579-587, 2011.

COSTA, F. de S.; BAYER, C.; ALBUQUERQUE, J. A.; FONTOURA, S. M. V. Aumento de matéria orgânica num latossolo bruno em plantio direto. Ciência Rural, Santa Maria, v. 34, p. 587-589, 2004.

FARIA, G. E. de; BARROS, N. F. de; SILVA, I. R. da; NOVAIS, R. F. de; PAIVA, A. O. Carbono orgânico total e das frações da matéria orgânica em diferentes distâncias da cepa de eucalipto. Cerne, Lavras, v. 14, n. 3, p. 259-266, 2008.

FELLER, C.; BEARE, M. H. Physical control of soil organic matter dynamics in the tropics. Geoderma, Amsterdam, v. 79, p. 69-116, 1997.

FERREIRA, A. de O.; SÁ, J. C. de M.; GIAROLA, N. F. B.; HARMS, M. G.; MIARA, S.; BAVOSO, M. A.; BRIEDIS, C. Variação na resistência tênsil de agregados em função do conteúdo de carbono em dois solos na região dos Campos Gerais. Revista Brasileira de Ciência do Solo, Campinas, v. 35 , n. 2, p. 437-446, 2011.

FRAGA, V. da S. Mudanças na matéria orgânica (c, n e p) de solos sob agricultura de subsistência. 2002.91 p. Tese (Doutorado) - Universidade Federal de Pernambuco, Recife, 2002.

KLUTHCOUSKI, J.; AIDAR, H.; COBUCI, T.; STONE, L. F.; THUNG, M. D. T.; BALBINO, L. C.; SILVA, C. C. da; OLIVEIRA, F. R. Integração lavoura-pecuária: estudo de caso vivenciado pela Embrapa Arroz e Feijão. In: PATERNIANI, E. (Ed.). Ciência, agricultura e sociedade. Brasília: Embrapa Informação e Tecnologia, 2006. p. 277-330.

LEITE, L. F. C.; MENDONÇA, E. S.; NEVES, J. C. L.; MACHADO, P. L. O. A.; GALVÃO, J. C. C. Estoques totais de carbono orgânico e seus compartimentos em argissolo sob floresta e sob milho cultivado com adubação mineral e orgânica. Revista Brasileira de Ciência do Solo, Campinas, v. 27, n. 5, p. 821-832, 2003.

MARTINS, E. de L.; CORINGA, J. do E. S.; WEBER, O. L. dos S. Carbono orgânico nas frações granulométricas e substâncias húmicas de um Latossolo Vermelho Amarelo distrófico: LVAd sob diferentes agrossistemas. Acta Amazônica, Manaus, v. 39, p. 655-660, 2009.

Cerne, Lavras, v. 18, n. 2, p. 215-222, abr./jun. 2012 
POWLSON, D. S.; BROOKES, P. C.; CHRISTENSEN, B. T. Measurement of soil microbial biomass provides an indication of changes in total soil organic matter due to straw incorporation. Soil Biology \& Biochemistry, Elmsford, v. 19, n. 2, p. $159-164,1987$.

RIBEIRO, P. H.; SANTOS, J. V. V. M.; COSER, S. M.; NOGUEIRA, N. O.; MARTINS, C. A. S. Adubação verde, os estoques de carbono e nitrogênio e a qualidade da matéria orgânica do solo. Revista Verde, Mossoró, v. 6, n. 1, p. 43-50, 2011.

RIBEIRO JÚNIOR, I. R. Análises estatísticas no SAEG. Viçosa, MG: UFV, 2001. 301 p.

RONDÔNIA. Governo Estadual. Planafloro: achievements and projects for Rondônia. Porto Velho: SEPLAN, 2002.

ROSCOE, R.; BUURMAN, P. Tillage effects on soil organic in density fractions of a Cerrado Oxisol. Soil and Tillage Research, Oxford, v. 70, p. 107-119, 2003.

ROSCOE, R.; MACHADO, P. L. O. A. Fracionamento físico do solo em estudos da matéria orgânica. Dourados: Embrapa Agropecuária Oeste, 2002. 86 p.
SHANG, C.; TIESSEN, H. Organic matter lability in a tropical oxisol: evidence from shifting cultivation, chemical oxidation, particle size, density, and magnetic fractionations. Soil Science, Baltimore, v. 162, p. 795-807, 1997.

SIX, J.; FREY, S. D.; THIES, R. K.; BATTEN, K. M. Bacterial and fungal contributions to carbon sequestration in agroecosystems. Soil Science Society America Journal, Madison, v. 70, p. 555-569, 2006.

TAVARES, R. L. M. Atributos químicos e biológicos de solos sob diferentes ecossistemas e adicionados de material vegetal de soja. 2010. 133 f. Dissertação (Mestrado) Universidade Estadual Paulista, Botucatu, 2010.

YEOMANS, J. C.; BREMNER, J. M. A rapid and precise method for routine determination of organic carbon in soil. Communications in Soil Science and Plant Analysis, New York, v. 19, p. 1467-1476, 1988.

ZINN, Y. L. Textural, mineralogical and structural controls on soil organic carbon retention in the Brazilian cerrados. 2005. 107 p. Thesis (Ph.D. in Philosophy) - Ohio State University, 2005.

Cerne, Lavras, v. 18, n. 2, p. 215-222, abr./jun. 2012 